\title{
A CONTEXT AWARE APPLICATION TO SUPPORT THE EXECUTION OF DAILY TASKS OF PEOPLE WITH COGNITIVE DISABILITIES
}

\author{
Luis Santiago Cuascota Chicaiza Iscuascota@espe.edu.ec \\ Rosa Graciela Guerrero Idrovo rgguerrero@espe.edu.ec \\ 15 de julio de 2020 \\ https://ieeexplore.ieee.org/abstract/document/9141076
}

\begin{abstract}
RESUMEN
La tecnología se ha visto poco involucrada en los modelos de educación especial para personas con discapacidades cognitivas, además existen normativas que apoyan a su inserción laboral en igualdad de condiciones, debido a las dificultades que presentan estas personas no es posible garantizar su inclusión. El presente trabajo tiene como propuesta el desarrollo de un prototipo de aplicación Android basada en tecnología beacons denominada "TK-2" para asistencia de personas con discapacidad cognitiva en la ejecución de tareas, está diseñada con actividades de dificultad ascendente y la toma de datos automática, que muestra resultados en la pantalla del dispositivo, gracias a esto los datos son visibles, precisos y confiables. En la ejecución de pruebas se consideraron a usuarios en base a la experiencia (medio y ninguno) en la actividad propuesta. Estos resultados se contrastaron para determinar que la aplicación contribuye a reducir paulatinamente los parámetros de evaluación (tiempo, errores y ayudas) hasta que el usuario comienza a realizar la actividad de forma independiente, además se entiende como TK-2 actúa en actividades que son poco frecuentes y las que son repetitivas.
\end{abstract}

\section{Palabras claves:}

- BEACONS

- DISCAPACIDAD COGNITIVA

- ASISTENCIA

- ENSEÑANZA

- APLICACIÓN MÓVIL 


\title{
A CONTEXT AWARE APPLICATION TO SUPPORT THE EXECUTION OF DAILY TASKS OF PEOPLE WITH COGNITIVE DISABILITIES
}

\author{
Luis Santiago Cuascota Chicaiza Iscuascota@espe.edu.ec \\ Rosa Graciela Guerrero Idrovo rgguerrero@espe.edu.ec \\ 15 de julio de 2020 \\ https://ieeexplore.ieee.org/abstract/document/9141076
}

\begin{abstract}
Technology has been little involved in the special education models for people with cognitive disabilities, and there are regulations that support their labour insertion under equal conditions, but due to the difficulties that these people present, it is not possible to guarantee their inclusion. The present work has as proposal the development of a prototype of Android application based on beacons technology called "TK-2" for the assistance of people with cognitive disabilities in the execution of tasks, which is designed with activities of ascending difficulty and automatic data collection, which shows results on the screen of the device, thanks to this the data are visible, accurate and reliable. In the execution of tests, users were considered based on the experience (average and none) in the proposed activity. These results were contrasted to determine that the application contributes to gradually reduce the evaluation parameters (time, errors and aids) until the user begins to perform the activity independently, also understood as TK-2 acts in activities that are rare and those that are repetitive.
\end{abstract}

\section{KEYWORDS:}

- BEACONS

- COGNITIVE IMPAIRMENT

- ASSISTANCE

- TEACHING

- MOBILE APPLICATION 